\title{
Impact of Nutrition on Phenotype in CFTR-deficient Mice
}

\author{
CHARLES-HENRY COTTART, ELISE BONVIN, COLETTE REY, DOMINIQUE WENDUM, JEAN-FRANÇOIS BERNAUDIN, \\ SYLVIE DUMONT, ELISABETH LASNIER, DOMINIQUE DEBRAY, ANNICK CLÉMENT, \\ CHANTAL HOUSSET, AND MONIQUE BONORA
}

\begin{abstract}
Inserm UMR-S U680 [C.-H.C., C.R., D.D., C.H.], Inserm UMR-S U719 [E.B., A.C., M.B.], Université Pierre et Marie Curie-Paris 6 Paris, 75012, France; EA3499 [J.-F.B.], Université Pierre et Marie Curie-Paris 6 [D.W., S.D.], Paris, 75012, France; EA 3499 [J.-F.B.], Université Pierre et Marie Curie-Paris 6, Paris, 75020, France; Service d'Anatomie Pathologique [D.W.], Service de Biochimie [E.L.], AP-HP Hôpital Saint-Antoine, Paris, 75012, France
\end{abstract}

\begin{abstract}
To elucidate the impact of nutrition in cystic fibrosis (CF), we compared the phenotypic traits of $\mathrm{Cftr}^{-1-}$ mice fed either a lipid-enriched liquid diet (Peptamen) or a standard chow combined with polyethylenglycol osmotic laxative (PEG), two strategies commonly used to prevent intestinal obstruction in CF mice. Survival, growth, liver, and ventilatory status were determined in $\mathrm{Cftr}^{--}$and $\mathrm{Cftr}^{+/+}$mice, followed-up until $120 \mathrm{~d}$. Ventilation was recorded in conscious animals using whole-body plethysmography. We found that the survival rate was similar in Peptamen and $\mathrm{PEG} \mathrm{Cftr}^{-/-}$mice. $\mathrm{Cftr}^{-/-}$mice had lower minute ventilation than $\mathrm{Cftr}^{+/+}$mice, whatever the diet. Both $\mathrm{Cftr}^{-1-}$ and $\mathrm{Cftr}^{+/+}$mice fed Peptamen displayed preadult growth delay compared with PEG-treated animals. Despite subsequent growth catch-up, $\mathrm{Cftr}^{-/}$mice remained smaller than $\mathrm{Cftr}^{+/+}$mice, whatever the diet. All Peptamen fed $\mathrm{Cftr}^{-/-}$mice showed hepatomegaly and liver steatosis, which also occurred but to a lesser extent in Peptamen fed $\mathrm{Cftr}^{+/+}$animals. Therefore, while both treatment strategies are similarly efficient to avoid high mortality at weaning, Peptamen induces preadult growth delay and liver steatosis. These effects of diet are important to consider in future animal studies and also prompt to evaluate high-energy diets in $\mathrm{CF}$ patients. (Pediatr Res 62: 528-532, 2007)
\end{abstract}

$\mathrm{C}^{\mathrm{s}}$ ystic fybrosis (CF) is among the most common genetic diseases. The organs affected in CF include the lungs, the gastrointestinal tract, the pancreas, and the liver (1). Approximately $15 \%$ of $\mathrm{CF}$ patients present with meconium ileus (i.e. neonatal intestinal obstruction), and more than $80 \%$ develop pancreatic insufficiency (2). While both intestinal and pancreatic dysfunctions contribute to malnutrition, there is evidence to indicate that the nutritional status may influence liver and lung injury in these patients (3-5). CF mice with a complete exon-10 knockout of the CFTR gene ( $\mathrm{Cftr}^{\mathrm{tm} 1 \mathrm{Unc}}$ ) (6) develop severe CF-like intestinal obstruction. This obstruction is lethal at birth or at weaning, unless prevented by special feeding. The most common strategy has been to feed the animals at weaning with Peptamen (Nestlé France, Marne la Vallée, France), a lipid-enriched liquid diet, initially designed to feed infants or young children who suffer malnutrition

Received March 20, 2007; accepted June 13, 2007.

Correspondence: Monique Bonora, Ph.D., Inserm, UMR-S U719, Hôpital SaintAntoine, Bâtiment Kourilsky, 184, rue du Faubourg Saint-Antoine, Paris, 75012, France; e-mail: bonora@st-antoine.inserm.fr

This work was supported in part by a grant from the association "Vaincre la Mucoviscidose." PEG (Transipeg) was provided by Roche-Nicolas and Peptamen was provided by Nestlé, France. (including those born with $\mathrm{CF}$ ). An alternative strategy to avoid intestinal obstruction in CF mice has been to supply them with an osmotic laxative, such as polyethylenglycol (PEG) (7). In this latter option, mice are maintained on a standard solid chow. Because the composition of Peptamen differs from that of a standard chow, for example, the proportion of lipids is higher while those of proteins and carbohydrates are lower, we hypothesized that the two regimens result in different nutritional status, and may thus result in different phenotypic traits of $\mathrm{CF}$ disease (8). To test this hypothesis and gain insight into the impact of nutrition on $\mathrm{CF}$ disease, we herein compared the phenotype of $\mathrm{Cftr}^{\mathrm{tm} 1 \mathrm{Unc}}$ mice fed either Peptamen or a standard diet with PEG, with particular attention to respiratory and liver alterations, which currently represent the two main causes of death in CF patients.

\section{MATERIALS AND METHODS}

Animals. Animals used in this study were male CF mice homozygous for the S489X mutation (Cftr ${ }^{\mathrm{tm} 1 \mathrm{Unc}}$ ) (6) back-crossed into C57BL/6 (three generations) $\left(\mathrm{Cftr}^{-1-}\right)$ and their normal littermates $\left(\mathrm{Cftr}^{+/+}\right)$. Mice were housed and bred at the CDTA-CNRS (Orléans, France) and obtained after weaning at 21-25 d of age. All experiments were performed in accordance with our Institutional Animal Care and Use Department (Direction Départementale des Services Vétérinaires de Paris, agreement no. B75-1201).

Experimental design. Mice were bred on corncob pellet bedding and maintained in a barrier facility unit under specific pathogen-free conditions with a 12-h light-dark cycle, in accordance with European recommendations. $\mathrm{Cftr}^{-1-}$ and $\mathrm{Cftr}^{+/+}$mice were randomly assigned at weaning (21-25 $\mathrm{d}$ of age) to one of the following regimens:

1. Standard: solid chow ad libitum with free access to water.

2. Standard + PEG: solid chow ad libitum with free access to a commercially available osmotic laxative containing PEG-3350 and electrolytes (Transipeg, Roche-Nicholas, Gaillard, France), which was continuously supplied at $6 \%$ in the drinking water. Because newly weaned $\mathrm{Cftr}^{-1-}$ mice are weak, solid chow was soaked with laxative during the first week after weaning.

3. Peptamen: liquid diet (Nestlé) ad libitum with free access to water. Peptamen was changed every $2 \mathrm{~d}$, as previously reported (9). The composition of Peptamen in comparison with that of standard chow is shown in Table 1.

Monitoring of survival and growth. To determine whether survival of $\mathrm{Cftr}^{-1-}$ mice was altered by the dietary regimen, survival of $\mathrm{Cftr}^{-1-}$ mice fed ad libitum either a standard chow $(n=12)$, a standard chow together with PEG $(n=26)$, or Peptamen liquid diet $(n=18)$ was compared with that of $\mathrm{Cftr}^{+/+}$littermates. Survival was calculated every $5 \mathrm{~d}$ until $60 \mathrm{~d}$ as the percentage of living animals in each group.

Abbreviations: CF, cystic fibrosis; PEG, polyethylenglycol; $\mathbf{V}_{\mathbf{E}}$, minute ventilation 
Table 1. Nutritional information on the main energetic components of Peptamen semi-elemental formula and standard mouse solid chow (AO3)

\begin{tabular}{lcc}
\hline & Peptamen (Nestlé) & AO3 Chow (Safe) \\
\hline Proteins (g/100 kcal) & 4.0 & 6.7 \\
Carbohydrates (g/100 kcal) & 12.7 & 16.2 \\
Lipids (g/100 kcal) & 3.7 & 1.6 \\
MC/MC + LC ratio & $70 \%$ & $<5 \%$ \\
\hline
\end{tabular}

MC, medium-chain lipids; LC, long-chain lipids.

Subsequently, part of these animals were followed-up for a longer period of time $(120 \mathrm{~d})$, to further examine their growth, liver and ventilatory status.

Respiratory physiology. All data were obtained in 120-d-old mice. Ventilatory parameters were recorded in a whole-body plethysmograph by the barometric method described by Bartlett and Tenney (10). The pressure signal as a result of breathing was detected by a differential pressure transducer (Validyne DP103/12; Validyne, Northridge, CA) connected to the animal chamber $(400 \mathrm{~mL})$ and to a reference chamber of the same volume. The spirogram was recorded and stored on a computer using respiratory acquisition software (CIO-DAS 1602/16 interface and ELPHY software) for analysis off-line. Calibration was performed at the beginning of experiments by several injections of $50 \mu \mathrm{L}$ of air into the chamber.

Each animal was weighed and placed in the chamber preheated at 28 $30^{\circ} \mathrm{C}$; a thermistal probe (BIO-BIT14) was inserted rectally and secured in place at the base of the tail and on the wall chamber. A protecting muff was placed around the mouse allowing it to feel secure and to be rapidly calmed. The ventilatory parameters and colonic and chamber temperature were recorded during $20 \mathrm{~min}$ at 5 -min interval while the mouse was breathing room air. The $\mathrm{CO}_{2}$ concentration in the chamber was always $<0.5 \%$. The following variables were measured and calculated by a computer-assisted method: minute ventilation $(\mathrm{VE})$ and its two components: tidal volume $(\mathrm{VT})$ and respiratory frequency (fR). For each 5-min recording, values were averaged on 50-100 contiguous breaths.

Blood and tissue collection. Mice aged $120 \mathrm{~d}$ were anesthetized with an intraperitoneal injection of ketamine $(80 \mathrm{mg} / \mathrm{kg}$ ) (Virbac, Carros Cedex, France) and xylazine (20 mg/kg) (Rompun, Bayer, Leverkusen, Germany) and the abdominal cavity was opened. Blood was collected from the vena cava for biochemical tests. The liver was harvested, immediately weighed, and immersed in $10 \%$ buffered formalin for $24 \mathrm{~h}$ before paraffin embedment. The chest was then opened, the trachea exposed, and the lungs perfused in situ with $10 \%$ ( $\mathrm{vol} / \mathrm{vol}$ ) neutral-buffered formalin under $5 \mathrm{~cm} \mathrm{H}_{2} 0$ pressure as recommended by Kent (personal communication). Thereafter, the trachea was ligated; the lungs were excised and immersed in 10\% formalin during $5 \mathrm{~d}$ before paraffin embedment.

Biochemical tests. Serum transaminase activities, i.e. aspartate aminotransferase (AST) and alanine aminotransferase (ALT), were measured at $37^{\circ} \mathrm{C}$ on an Olympus AU 640 analyzer, using bioMerieux (Marcy l'Etoile, France) reagent.

Histology. All tissue samples were paraffin-embedded and cut into $4-\mu \mathrm{m}-$ thick sections. Tissue sections were stained with hematoxylin and eosin, and examined under light microscopy, by an experienced pathologist blinded for the genotype and dietary regimen. Liver steatosis was graded according to the percentage of hepatocytes containing cytoplasmic vacuoles, as follows: mild $(\leq 10 \%)$; moderate $(>10 \%$ and $\leq 30 \%)$; and severe $(>30 \%)$.

Statistical analysis. All values are given as means \pm SD. Statistical comparisons were performed using a nonparametric Wilcoxon-MannWhitney test, which does not assume a normal distribution. A $p$ value $<0.05$ was considered as statistically significant.

\section{RESULTS}

Survival. In the group of $\mathrm{Cftr}^{--}$mice, 10 out of 12 animals died within $10 \mathrm{~d}$ after weaning, when maintained on standard chow. By contrast, $77 \%$ and $73 \%$ of $\mathrm{Cftr}^{--}$mice fed Peptamen or a standard chow + PEG, respectively, were alive after $60 \mathrm{~d}$ (Fig. 1). All age-matched $\mathrm{Cftr}^{+/+}$mice, whatever was the regimen, were alive after $60 \mathrm{~d}$. Therefore, the lifespan of $\mathrm{Cftr}^{-/-}$mice was greatly prolonged by either one of Peptamen or PEG regimens. In the animals followed-up for a longer period of time, survival was stable up to $120 \mathrm{~d}$.

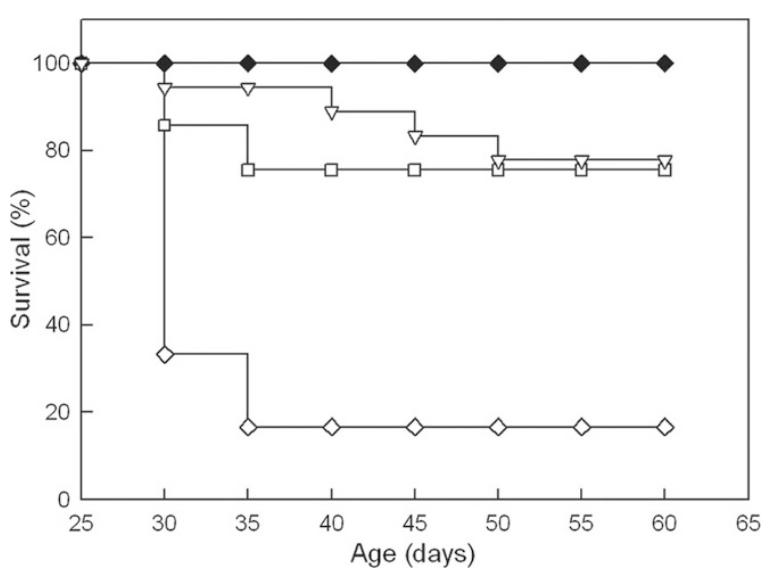

Figure 1. Survival rates from weaning until $60 \mathrm{~d}$. Survival rates from weaning until $60 \mathrm{~d}$ of $\mathrm{Cftr}^{+/+}$mice with or without treatment $(\bullet, n=35)$, standard chow fed $\mathrm{Cftr}^{-1-}$ mice $(\diamond, n=12)$, standard + PEG Cftr ${ }^{-/-}$mice $(\square$, $n=26)$, and Peptamen $\mathrm{Cftr}^{-1-}$ mice $(\nabla, n=18)$.
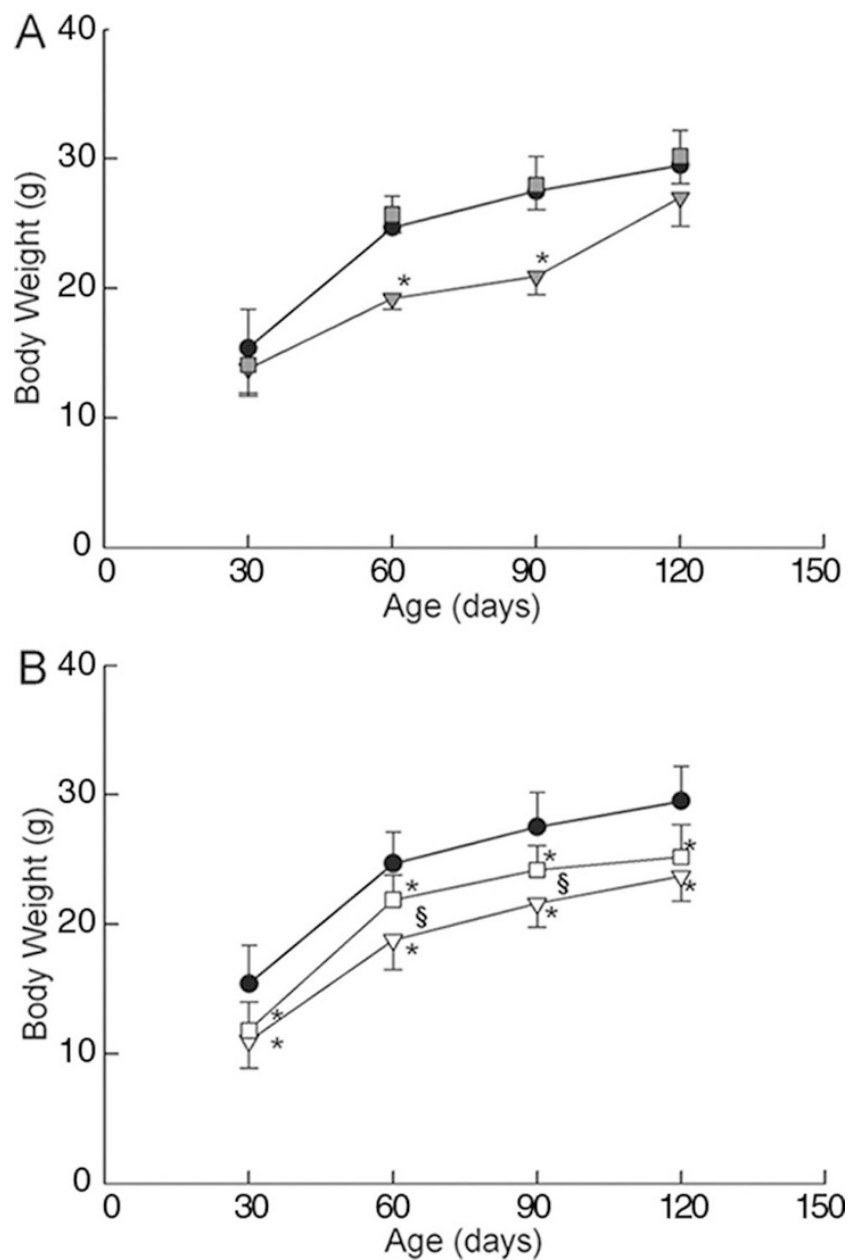

Figure 2. Weight gain between 30 and $120 \mathrm{~d}$ of age. Weight gain from $30 \mathrm{~d}$ until $120 \mathrm{~d}$ of age in $(A)$ : standard $(\boldsymbol{\bullet}, n=13)$, Peptamen $(\nabla, n=5)$, and standard + PEG $(\square, n=8) \mathrm{Cftr}^{+/+}$mice; and $(B)$ : standard $\mathrm{Cftr}^{+/+}$mice $(\boldsymbol{\bullet}$, $n=13)$, Peptamen $(\nabla, n=7)$ and standard + PEG ( $\square, n=7) \mathrm{Cftr}^{-1-}$ mice. $* p<0.05$ compared with standard $\mathrm{Cftr}^{+/+}$mice; $\$ p<0.05$ compared with standard $+\mathrm{PEG} \mathrm{Cftr}^{-1-}$ mice. Body weights are expressed as means $\pm \mathrm{SD}$.

Growth. The growth of $\mathrm{Cftr}^{-1-}$ mice that were fed either Peptamen or a standard chow + PEG, was compared with that of age-matched $\mathrm{Cftr}^{+/+}$mice that were under the same regi- 
men or under standard chow (without PEG), this latter group being taken as a reference (Fig. 2). While all $\mathrm{Cftr}^{+/+}$mice had similar body weights at the age of $30 \mathrm{~d}$, during subsequent preadult period (between 30 and $60 \mathrm{~d}$ ), weight gain was significantly lower in the subgroup of Peptamen-fed animals, than in those under standard or PEG regimen $(+5.4 \pm 1.5 \mathrm{~g}$ versus $9.2 \pm 2.6 \mathrm{~g}$ and $+11.6 \pm 1.5 \mathrm{~g}$, respectively). Later on (from 60 to $120 \mathrm{~d}$ ), a growth catch-up occurred in Peptamenfed $\mathrm{Cftr}^{+/+}$animals that gained $7.8 \pm 1.9 \mathrm{~g}$ versus $4.8 \pm 1.8 \mathrm{~g}$ and $4.5 \pm 1.6 \mathrm{~g}$, in animals under standard and PEG regimens, respectively (Fig. $2 A$ ).

Figure $2 B$ shows that, at $30 \mathrm{~d}$ of age, $\mathrm{Cftr}^{-/-}$mice were significantly smaller than standard $\mathrm{Cftr}^{+/+}$mice. Subsequent weight gain during the entire preadult and adult period was not significantly different between Peptamen-fed $\mathrm{Cftr}^{-/-}(+12.7 \pm$ $2.1 \mathrm{~g})$, PEG-treated $\mathrm{Cftr}^{--}(+13.5 \pm 1.9 \mathrm{~g})$, and standard $\mathrm{Cftr}^{+/+}$mice $(+14.0 \pm 2.0 \mathrm{~g})$, but during preadult period (30-60 d), weight gain was significantly lower in Peptamen than in $\mathrm{PEG} \mathrm{Cftr}^{-/-}$mice $(+7.8 \pm 1.5 \mathrm{~g}$ versus $+10.1 \pm 2.1 \mathrm{~g}$, respectively). However, after $120 \mathrm{~d}$, neither Peptamen nor PEG Cftr ${ }^{-/-}$mice had caught-up growth on standard $\mathrm{Cftr}^{+/+}$ mice, and $\mathrm{Cftr}^{-1-}$ mice in both groups were smaller than standard $\mathrm{Cftr}^{+/+}$mice.

These data indicate that mice with $\mathrm{Cftr}^{-/-}$genotype failed to catch-up growth retardation present at weaning. Unexpectedly, lipid-enriched diet, although designed for malnutrition, induced a growth delay during the preadult period in both $\mathrm{Cftr}^{+/+}$and $\mathrm{Cftr}^{-1-}$ mice.

Lung phenotype. Ventilation was recorded in conscious mice breathing room air, at the age of $120 \mathrm{~d}$. As shown in Figure $3 A$, baseline minute ventilation $(\mathrm{VE})$ was not different between the three groups of $\mathrm{Cftr}^{+/+}$mice, fed either standard chow, standard chow with PEG, or Peptamen. In $\mathrm{Cftr}^{-/-}$mice, $\mathrm{V}_{\mathrm{E}}$ was significantly lower than in $\mathrm{Cftr}^{+/+}$mice, without any difference between PEG- and Peptamen-fed animals.

Because minute ventilation is generally dependent upon body weight, we analyzed the relationship between both parameters in $\mathrm{Cftr}^{+/+}$and $\mathrm{Cftr}^{-/-}$mice (Fig. 3B). This analysis showed a significant correlation between both parameters in $\mathrm{Cftr}^{+/+}$animals $(r=0.54, p<0.05)$ while in $\mathrm{Cftr}^{-/-}$mice, $\mathrm{VE}$ did not increase with body weight. As a consequence, we did not find it appropriate to use $V_{E}$ to body weight ratios for comparison between the two groups. To minimize the impact of body weight, we considered a narrow range of overlapping body weights (24-30 g) (Fig. 3B, dotted lines). Within this range, the difference between $\mathrm{Cftr}^{-/}$and $\mathrm{Cftr}^{+/+}$mice remained highly significant $\left(\mathrm{V}_{\mathrm{E}} \pm \mathrm{SD}=44.3 \pm 6.1\right.$ versus $57.5 \pm 6.2$, $p<0.001$ ).

Histopathological examination of the lungs in the different groups did not show any inflammation, luminal obstruction, or fibrosis. Only a few distended areas of alveolar air spaces, mainly centrally located, were occasionally observed in both Peptamen- and PEG-treated $\mathrm{Cftr}^{-1-}$ mice (data not shown).

We conclude that $\mathrm{Cftr}^{-1-}$ genotype by itself causes a ventilation defect, with little or no influence of inflammation, nutritional, or growth status.

Liver phenotype. The occurrence of liver damage was first evaluated by measuring the liver/body weight ratio. In com-
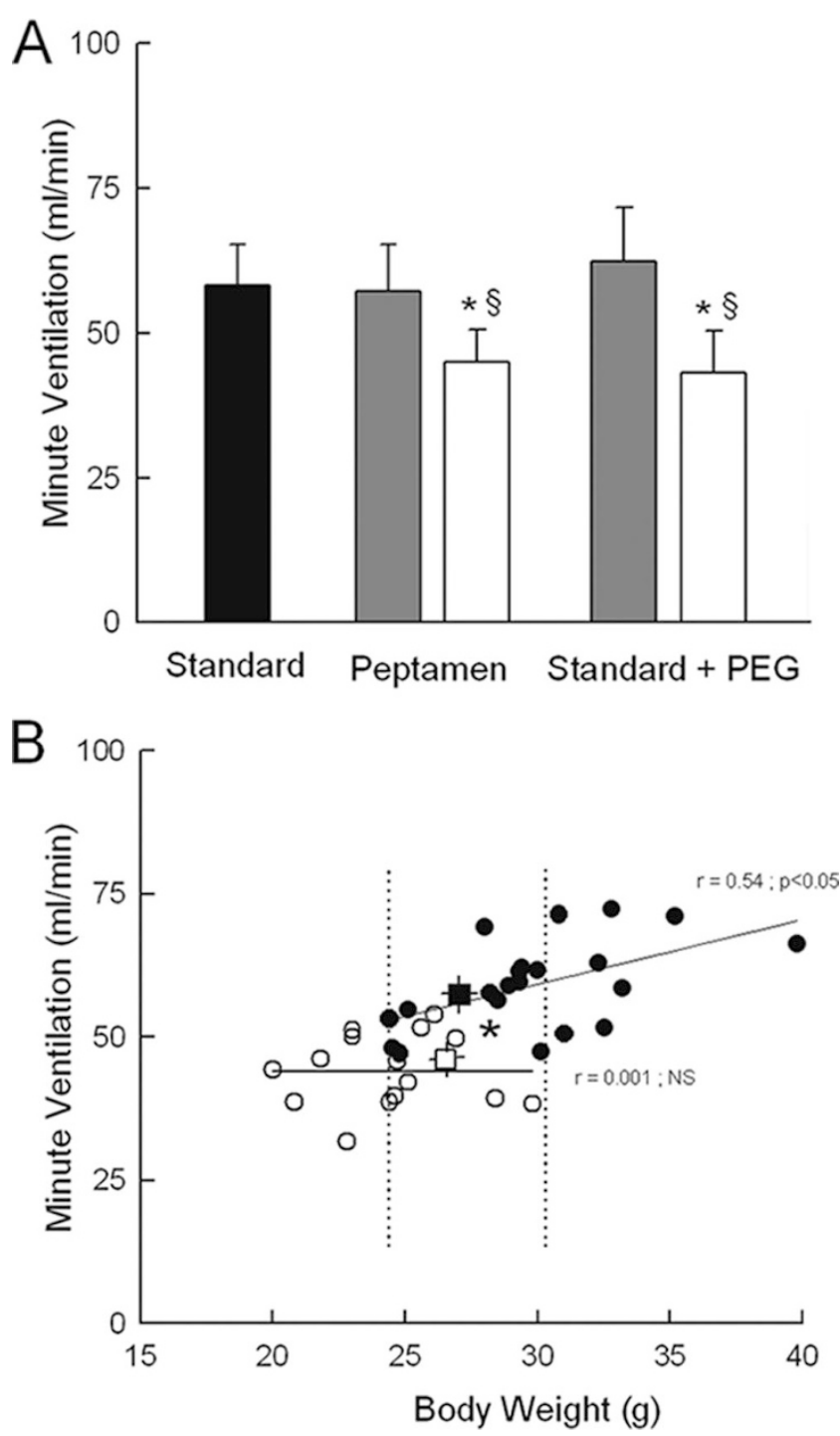

Figure 3. Minute ventilation in 120-d-old mice. (A) Mean values $( \pm$ SD) of minute ventilation $(\mathrm{mL} / \mathrm{min})$ measured in standard $\mathrm{Cftr}^{+/+}$mice $(\boldsymbol{\square}, n=10)$, Peptamen and standard + PEG $\mathrm{Cftr}^{+/+}$mice $(\square, n=5$ and $n=6$, respectively) and Peptamen and standard + PEG $\mathrm{Cftr}^{-/-}$mice ( $\square, n=7$ and $n=8$, respectively). (B) Relationship between minute ventilation $(\mathrm{mL} / \mathrm{min})$ and body weight $(\mathrm{g})$ in standard, Peptamen and standard + PEG Cftr ${ }^{+/+}$mice $(\bullet, n=21)$ and Peptamen and standard + PEG $\mathrm{Cftr}^{-1-}$ mice $(\bigcirc, n=15)$; dotted lines limit a restricted body weight range (24-30 g) for which mean values $( \pm \mathrm{SD})$ of minute ventilation and body weight for $\mathrm{Cftr}^{+/+}$and $\mathrm{Cftr}^{-/}$ $\square$ mice are given. The regression lines fitted for values of each group of mice with correlation coefficients $(r)$ and $p$ value are shown $(B)$. All measurements were performed in 120 -d-old animals. ${ }^{*} p<0.05$ compared with standard $\mathrm{Cftr}^{+/+} ; \S p<0.05$ compared with Peptamen or standard + PEG $\mathrm{Cftr}^{+/+}$ mice.

parison with $\mathrm{Cftr}^{+/+}$mice on standard diet, neither $\mathrm{Cftr}^{+/+}$ nor $\mathrm{Cftr}^{-1-}$ mice treated with PEG showed significant differences in liver/body weight ratios (Fig. 4). Peptamen feeding by itself did not induce any significant change in liver/body weight ratios in $\mathrm{Cftr}^{+/+}$mice, but caused hepatomegaly in $\mathrm{Cftr}^{-/-}$mice (Fig. 4). While the liver was histologically normal in all $\mathrm{Cftr}^{+/+}(n=6)$ and $\mathrm{Cftr}^{-/-}(n=6)$ animals treated with PEG (Fig. 5, $A$ and $C$ ), all $\mathrm{Cftr}^{-/-}$and some $\mathrm{Cftr}^{+/+}$mice fed Peptamen displayed macrovacuolar periportal steatosis. Out of five Peptamen-fed $\mathrm{Cftr}^{+/+}$mice, three showed steatosis, 


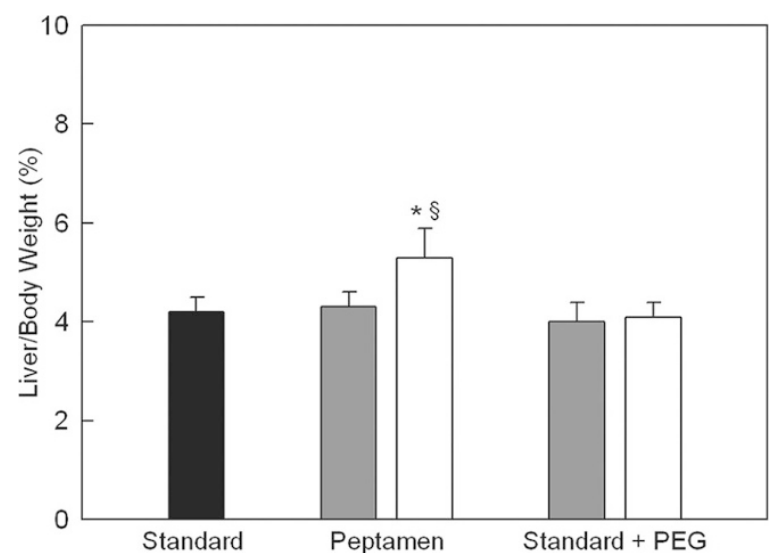

Figure 4. Liver/body weight ratio in 120-d-old mice. Liver/body weight ratios (mean values $\pm \mathrm{SD}$ ) in 120-d-old $\mathrm{Cftr}^{+/+}$animals under standard $(\mathbf{\square}, n=$ 4), Peptamen or standard + PEG $\mathrm{Cftr}^{+/+}$mice $(\square, n=5$ and $n=7$, respectively); Peptamen and standard + PEG $\mathrm{Cftr}^{-1-}$ mice $(\square, n=6$ in both groups). $* p<0.05$ compared with standard $\mathrm{Cftr}^{+/+}$mice; $\$ p<0.05$ compared with Peptamen $\mathrm{Cftr}^{+/+}$mice.
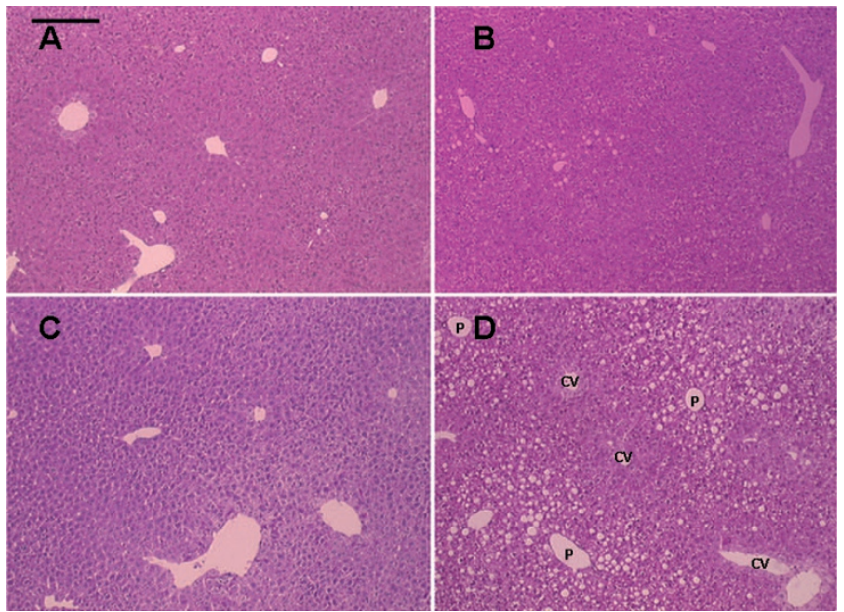

Figure 5. Histologic examination of the liver of 120-d-old mice. Hematoxylin/eosin staining of the liver from 120-d-old mice, showing $(A)$ normal liver histology in standard + PEG $\mathrm{Cftr}^{+/+}$mice; $(B)$ mild periportal macrovacuolar steatosis in Peptamen $\mathrm{Cftr}^{+/+}$mice; $(C)$ normal liver histology in standard + PEG $\mathrm{Cftr}^{-/-}$mice; and $(D)$ moderate peri-portal macrovacuolar steatosis in a Peptamen $\mathrm{Cftr}^{-/-}$mice. Scale bar $=200 \mu \mathrm{m}$. $C V$, central vein; $P$, portal tract.

which was graded as mild in two (Fig. 5B) and moderate in one. Steatosis was graded as moderate $(>10 \%$ and $\leq 30 \%)$ in three out of six Peptamen-fed $\mathrm{Cftr}^{-1-}$ animals, as illustrated in Figure $5 D$, and as mild $(\leq 10 \%)$ in the remaining three. Peptamen also induced steatosis in $\mathrm{Cftr}^{+/+}$animals, although to a lesser extent than in $\mathrm{Cftr}^{-1-}$. No other histologic abnormality, including biliary obstruction or portal tract inflammation, was detected. Moreover, there was no difference in the serum levels of transaminases (AST and ALT) between the different groups.

These results indicate that the lipid-enriched liquid diet Peptamen induces liver steatosis, which is associated with hepatomegaly and tends be more severe, in $\mathrm{Cftr}^{-1-}$ genotypic background.

\section{DISCUSSION}

On the basis of analyses in $\mathrm{Cftr}^{--}$mice, the present study provides evidence that CFTR genetic defect may cause 1) growth failure, 2) hypoventilation, and 3) predisposition to liver steatosis. Premature death at weaning to standard diet in $\mathrm{Cftr}^{-1-}$ mice, which was previously shown to occur as a result of intestinal obstruction, was herein prevented with similar efficiency by an osmotic laxative (PEG) and a lipid-enriched liquid diet (Peptamen). While the degree of hypoventilation was similar in animals fed either Peptamen or a standard chow with PEG, the dietary regimen had an impact on growth development and on the occurrence of liver steatosis.

It has been reported that the high mortality rate of CFTR knockout mice soon after weaning was related to intestinal obstruction with solid food. The administration of Peptamen, an easily digestible low-residue liquid diet, was first proposed by Eckman et al. (11) to prevent intestinal obstruction. These authors demonstrated that this liquid diet markedly increased the lifespan in $\mathrm{Cftr}^{-/-}$mice, and that $88 \%$ of treated mice reached maturity. Subsequently, it was shown that the addition of an osmotic laxative (PEG) in the drinking water also greatly prolonged survival of $\mathrm{Cftr}^{-1-}$ mice (7). The present study shows that Peptamen and PEG used in the same experimental conditions have similar beneficial effects on survival, in CFTR knockout mice.

Under both dietary regimens, however, surviving $\mathrm{Cftr}^{-1-}$ mice remain consistently smaller than $\mathrm{Cftr}^{+/+}$controls. This finding is reminiscent of the failure to thrive observed in $\mathrm{CF}$ children (3,12-14). In addition, weight growth was significantly delayed in the preadult period in Peptamen-fed CF mice compared with PEG-treated CF mice, indicating that Peptamen diet is not the best option at least in mouse species.

In most studies, lung pathology in $\mathrm{Cftr}^{-/-}$mice has been assessed histologically. Only minor lesions of the respiratory tract have been reported, almost exclusively in congenic $\mathrm{Cftr}^{-/-}$mice $(15,16)$. However, the consequences of CFTR defect on pulmonary function have been rarely investigated in mouse models $(9,17,18)$. In the present study, pulmonary function in $\mathrm{Cftr}^{-1-}$ mice was tested by measuring the basal minute ventilation $\left(\mathrm{V}_{\mathrm{E}}\right)$ in breathing air. The results show that $\mathrm{VE}_{\mathrm{E}}$ is lower in $\mathrm{Cftr}^{-/}$compared with $\mathrm{Cftr}^{+/+}$mice, irrespective of the dietary regimen. Although $\mathrm{V}_{\mathrm{E}}$ and body weight are normally positively correlated (19) as observed here in $\mathrm{Cftr}^{+/+}$animals, the decrease in ventilation noted in $\mathrm{Cftr}^{-1-}$ mice cannot be entirely attributed to their underweight. First, VE was not correlated with body weight in these mice. Second, within a restricted range of similar body weights, VE values from $\mathrm{Cftr}^{-/}$were still significantly lower than those from $\mathrm{Cftr}^{+/+}$animals. Low minute ventilation associated with CFTR defect may thus alter the control of breathing and contribute to lung disease. We previously showed that, while the ventilatory response to hypoxia was clearly diminished in juvenile (60-d-old) $\mathrm{Cftr}^{--}$mice, baseline minute ventilation was similar to that of their $\mathrm{Cftr}^{+/+}$littermates (17). The decrease in baseline minute ventilation found in 120-d-old $\mathrm{Cftr}^{-1-}$ mice may be explained by a progressive impairment in 
respiratory mechanics that occurs with aging, as previously suggested (18).

While life expectancy continuously improves in CF patients, hepatic manifestations become increasingly problematic. After cardiorespiratory and transplantation complications, liver disease represents a significant cause of death, in these patients (20). The type and severity of CF hepatic manifestations are both highly variable and their mechanisms are poorly understood. It is hypothesized that biliary-type lesions, resulting from the defective expression of CFTR in cholangiocytes (21-24), are the major pathogenic event leading to end-stage liver disease in CF. However, the most common hepatic lesion recognized in CF patients (23-67\%) at any age, is steatosis $(20,25)$. Even though its pathogenesis is poorly understood, liver steatosis is generally ascribed to epigenetic mechanisms related in particular to nutritional deficiencies (e.g. in essential fatty acids) (25). Consistent with this view, we show here that nutritional factors are required for steatosis to develop. No steatosis was noted in PEG treated mice irrespective of the genotype. In contrast, hepatic steatosis developed in Peptamen-fed $\mathrm{Cftr}^{-/-}$and $\mathrm{Cftr}^{+/+}$mice suggesting that steatosis results from the high fat content of this liquid diet. Furthermore, $\mathrm{Cftr}^{-1-}$ mice tend to be more severely affected than $\mathrm{Cftr}^{+/+}$mice, in agreement with the results of Beharry et al. (26). This finding, together with the fact that hepatomegaly was restricted to $\mathrm{Cftr}^{---}$animals, suggests that the loss of CFTR contributes to the development of liver steatosis. No inflammatory changes were seen in the liver of CFTR knockout animals, but in the same knockout mouse model bred into a congenic C57BL/6J background, Durie et al. (27) demonstrated that the severity of liver disease progressed with aging and that pathologic changes in the liver, including steatosis, cholangitis, and fibrosis, became evident after 3 months of age. Although steatosis has long been considered as a benign condition, we hypothesize that on a particular genetic background or that with aging, steatosis may progress to more serious fibrotic liver disease as reported in non-CF adult patients $(28,29)$.

The importance of diet in CF patients has been previously outlined $(3,30)$. Optimizing growth with a high-energy diet is recommended. The present findings indicate that both PEG and Peptamen strategies are similarly efficient to avoid the high mortality at weaning, but a high-fat diet may induce growth retardation during the preadult period and also triggers liver steatosis. These effects of diet are important to consider in future animal studies and also prompt to evaluate different types of high-energy diets in CF patients.

Acknowledgments. The authors thank the members of the CNRS CDTA (Centre de Développement des Techniques Avancées pour l'Expérimentation Animale, Orléans, France), in particular M.-F. Bertrand, for providing mice and Isabelle Renaud for her care of the animals in the St-Antoine facilities.

\section{REFERENCES}

1. Zielenski J 2000 Genotype and phenotype in cystic fibrosis. Respiration 67:117-133
2. Colombo C, Apostolo MG, Ferrari M, Seia M, Genoni S, Giunta A, Sereni LP 1994 Analysis of risk factors for the development of liver disease associated with cystic fibrosis. J Pediatr 124:393-399

3. Pencharz PB, Durie PR 2000 Pathogenesis of malnutrition in cystic fibrosis, and its treatment. Clin Nutr 19:387-394

4. Lamireau T, Monnereau S, Martin S, Marcotte JE, Winnock M, Alvarez F 2004 Epidemiology of liver disease in cystic fibrosis: a longitudinal study. J Hepatol 41:920-925

5. Konstan MW, Butler SM, Wohl ME, Stoddard M, Matousek R, Wagener JS, Johnson CA, Morgan WJ 2003 Growth and nutritional indexes in early life predict pulmonary function in cystic fibrosis. J Pediatr 142:624-630

6. Snouwaert JN, Brigman KK, Latour AM, Malouf NN, Boucher RC, Smithies O, Koller BH 1992 An animal model for cystic fibrosis made by gene targeting. Science 257:1083-1088

7. Clarke LL, Gawenis LR, Franklin CL, Harline MC 1996 Increased survival of CFTR knockout mice with an oral osmotic laxative. Lab Anim Sci 46:612-618

8. Freedman SD, Katz MH, Parker EM, Laposata M, Urman MY, Alvarez JG 1999 A membrane lipid imbalance plays a role in the phenotypic expression of cystic fibrosis in $\operatorname{cftr}(-/-)$ mice. Proc Natl Acad Sci U S A 96:13995-14000

9. Kent G, Oliver M, Foskett JK, Frndova H, Durie P, Forstner J, Forstner GG, Riordan JR, Percy D, Buchwald M 1996 Phenotypic abnormalities in long-term surviving cystic fibrosis mice. Pediatr Res 40:233-241

10. Bartlett D, Jr. Tenney SM 1970 Control of breathing in experimental anemia. Respir Physiol 10:384-395

11. Eckman EA, Cotton CU, Kube DM, Davis PB 1995 Dietary changes improve survival of CFTR S489X homozygous mutant mouse. Am J Physiol 269:L625-L630

12. Rosenberg LA, Schluchter MD, Parlow AF, Drumm ML 2006 Mouse as a model of growth retardation in cystic fibrosis. Pediatr Res 59:191-195

13. Lai HC, Kosorok MR, Sondel SA, Chen ST, FitzSimmons SC, Green CG, Shen G, Walker S, Farrell PM 1998 Growth status in children with cystic fibrosis based on the National Cystic Fibrosis Patient Registry data: evaluation of various criteria used to identify malnutrition. J Pediatr 132:478-485

14. Zemel BS, Jawad AF, FitzSimmons S, Stallings VA 2000 Longitudinal relationship among growth, nutritional status, and pulmonary function in children with cystic fibrosis: analysis of the Cystic Fibrosis Foundation National CF Patient Registry. J Pediatr 137:374-380

15. Kent G, Iles R, Bear CE, Huan LJ, Griesenbach U, McKerlie C, Frndova H, Ackerley C, Gosselin D, Radzioch D, O’Brodovich H, Tsui LC, Buchwald M, Tanswell AK 1997 Lung disease in mice with cystic fibrosis. J Clin Invest 100:3060-3069

16. Haston CK, McKerlie C, Newbigging S, Corey M, Rozmahel R, Tsui LC 2002 Detection of modifier loci influencing the lung phenotype of cystic fibrosis knockout mice. Mamm Genome 13:605-613

17. Bonora M, Bernaudin JF, Guernier C, Brahimi-Horn MC 2004 Ventilatory responses to hypercapnia and hypoxia in conscious cystic fibrosis knockout mice Cftr-/-. Pediatr Res 55:738-746

18. Cohen JC, Lundblad LK, Bates JH, Levitzky M, Larson JE 2004 The "Goldilocks effect" in cystic fibrosis: identification of a lung phenotype in the cftr knockout and heterozygous mouse. BMC Genet 5:21-26

19. Mortola JP, Matsuoka T, Saiki C, Naso L 1994 Metabolism and ventilation in hypoxic rats: effect of body mass. Respir Physiol 97:225-234

20. Colombo C, Battezzati PM 2004 Liver involvement in cystic fibrosis: primary organ damage or innocent bystander? J Hepatol 41:1041-1044

21. Cohn JA, Strong TV, Picciotto MR, Nairn AC, Collins FS, Fitz JG 1993 Localization of the cystic fibrosis transmembrane conductance regulator in human bile duct epithelial cells. Gastroenterology 105:1857-1864

22. Scoazec JY, Bringuier AF, Medina JF, Martinez-Anso E, Veissiere D, Feldmann G, Housset C 1997 The plasma membrane polarity of human biliary epithelial cells: in situ immunohistochemical analysis and functional implications. J Hepatol 26:543-553

23. Dray-Charier N, Paul A, Scoazec JY, Veissiere D, Mergey M, Capeau J, Soubrane O, Housset C 1999 Expression of delta F508 cystic fibrosis transmembrane conductance regulator protein and related chloride transport properties in the gallbladder epithelium from cystic fibrosis patients. Hepatology 29:1624-1634

24. Kinnman N, Lindblad A, Housset C, Buentke E, Scheynius A, Strandvik B, Hultcrantz R 2000 Expression of cystic fibrosis transmembrane conductance regulator in liver tissue from patients with cystic fibrosis. Hepatology 32:334340

25. Lindblad A, Glaumann H, Strandvik B 1999 Natural history of liver disease in cystic fibrosis. Hepatology 30:1151-1158

26. Beharry S, Ackerley C, Corey M, Kent G, Heng YM, Christensen H, Luk C, Yantiss RK, Nasser IA, Zaman M, Freedman SD, Durie PR 2007 Long-term docosahexaenoic acid therapy in a congenic murine model of cystic fibrosis. Am J Physiol Gastrointest Liver Physiol 292:G839-G848

27. Durie PR, Kent G, Phillips MJ, Ackerley CA 2004 Characteristic multiorgan pathology of cystic fibrosis in a long-living cystic fibrosis transmembrane regulator knockout murine model. Am J Pathol 164:1481-1493

28. Ratziu V, Poynard T 2006 Assessing the outcome of nonalcoholic steatohepatitis? It's time to get serious. Hepatology 44:802-805

29. Falck-Ytter Y, Younossi ZM, Marchesini G, McCullough AJ 2001 Clinical features and natural history of nonalcoholic steatosis syndromes. Semin Liver Dis 21:17-26

30. Peretti N, Marcil V, Drouin E, Levy E 2005 Mechanisms of lipid malabsorption in cystic fibrosis: the impact of essential fatty acids deficiency. Nutr Metab (Lond) 2:11 